\title{
Recommendations of the Subcommittee on the taxonomy of Campylobacter and related bacteria
}

\author{
P. Vandamme ${ }^{1}$ and S. L. W. On ${ }^{2}$
}

Author for correspondence: P. Vandamme. Tel: +329264 8093. Fax: +329264 8195.

e-mail: peter.vandamme@rug.ac.be

1 Laboratorium voor Farmaceutische Microbiologie, Universiteit Gent, Harelbekestraat 72, B-9000 Gent, Belgium

2 Danish Veterinary Laboratory, Copenhagen $\checkmark$, Denmark
The ICSB Subcommittee on the taxonomy of Campylobacter and related bacteria has discussed several contemporaneous issues and makes the following recommendations. (i) The reported synonymy between Campylobacter coli and Campylobacter hyoilei was based on valid taxonomic arguments. The subcommittee therefore discourages the use of the name $\boldsymbol{C}$. hyoilei. (ii) The revised infrasubspecific nomenclature of Campylobacter sputorum is endorsed. C. sputorum is subdivided into C. sputorum biovar sputorum (characterized by the absence of catalase and urease activity); $C$. sputorum biovar faecalis (characterized by catalase but not urease activity); and C. sputorum biovar paraureolyticus (characterized by urease, but not catalase activity). (iii) The subcommittee points out that 'Flexispira rappini' is a taxon that is circumscribed by means of morphological criteria. It encompasses multiple Helicobacter species, including Helicobacter bilis and Helicobacter trogontum. (iv) Finally, the subcommittee wishes to point out that the etymology of several specific or subspecific epithets of Campylobacter taxa has been corrected and that the spelling of the epithet 'fecalis' was corrected to 'faecalis'.

Keywords: Campylobacter, ICSB subcommittee recommendations, nomenclature
One of the tasks of taxonomic subcommittees of the International Committee on Systematic Bacteriology (ICSB), now known as the International Committee on Systematics of Prokaryotes (ICSP), is to make recommendations regarding taxonomic procedures, changes in nomenclature, recognition of types of various taxa, or classification. In the past years, statements related to several of these issues have appeared in the minutes of the meetings of the subcommittee. However, the statutes of the ICSB/ ICSP specify that such statements should also be submitted as separate papers (Article 9 regarding organization and functions of the subcommittees on taxonomy). The present manuscript summarizes the conclusions concerning four issues that were discussed during recent meetings of the ICSB Subcommittee on the taxonomy of Campylobacter and related bacteria.

Prepared by the authors on behalf of the IUMS International Committee on Systematic Bacteriology Subcommittee on Campylobacter and related bacteria.

\section{Taxonomic status of Campylobacter hyoilei}

The taxonomic position of 11 isolates from lesions of proliferative enteritis in pigs was studied by Alderton et al. (1995). They considered the strains to represent a species closely related to Campylobacter coli and Campylobacter jejuni and proposed the name Campylobacter hyoilei (Alderton et al., 1995). The taxonomic position of $C$. hyoilei was reevaluated by Vandamme et al. (1997) by using a range of phenotypic and genotypic methods and, crucially, a classical quantitative DNA-DNA hybridization method. These data showed $C$. hyoilei to be indistinguishable from $C$. coli. Vandamme et al. (1997) proposed that the two species be regarded as synonymous, with $C$. coli taking nomenclatural precedence. The subcommittee members agreed to discourage the use of the name $C$. hyoile $i$ in favour of $C$. coli. It was nonetheless noted that strains originally described as $C$. hyoilei may represent a variant of $C$. coli that is highly adapted for the porcine enteric tract, with pathologic consequences for the animal. Therefore, the epithet 'hyoilei' could in principle be revived as an infrasubspecific designation, 
if reliable pathogenic, phenotypic or genetic traits can be determined for identification.

\section{Revised infrasubspecific nomenclature of Campylobacter sputorum}

Campylobacter strains isolated from the human oral cavity and the genital tract of bulls were initially believed to be related at the subspecies level on the basis of their extensive biochemical similarities, and were named $C$. sputorum subsp. sputorum and $C$. sputorum subsp. bubulus, respectively (Véron \& Chatelain, 1973). Subsequent DNA hybridization studies (Roop et al., 1985) revealed a high level of DNA-DNA relatedness between these taxa, and also towards 'Campylobacter fecalis' (from sheep faeces). Limited biochemical variation between these taxa had been noted and thus Roop et al. (1985) proposed that the aforementioned taxa be referred to as sourcespecific biovars of $C$. sputorum (biovar sputorum, biovar bubulus, and biovar fecalis, respectively). The legitimacy of biovar bubulus as a distinct taxon was questioned when the tests used to distinguish biovar sputorum from biovar bubulus were found to be poorly reproducible, even when using highly standardized conditions for testing (On et al., 1994, 1998). The absolute validity of the source-specific biovar concept was also challenged since some $C$. sputorum strains from sheep and pigs could not be distinguished from those of bovine and human origin (On et al., 1994, 1998). The recent identification of urease-positive isolates of C. sputorum from cattle faeces resulted in the proposal of a new biovar structure, defined by reactions in two simple and reproducible tests (catalase and urease). C. sputorum biovar sputorum strains do not produce catalase, nor urease; $C$. sputorum biovar faecalis strains produce catalase but not urease; and $C$. sputorum biovar paraureolyticus strains produce urease, but not catalase. None of these biovars is host specific. The subcommittee agreed to endorse the revised biovar nomenclature of C. sputorum.

\section{Taxonomic status of 'Flexispira rappini'}

'Flexispira rappini' is a provisional name given to Gram-negative, microaerobic, motile, spindle-shaped bacteria with spiral periplasmic fibres and bipolar tufts of sheathed flagella. Strains with this distinctive morphology have been isolated from various sources including aborted lambs, canine faeces and gastric mucosa, intestinal mucosa of laboratory mice, and pig intestines (Bryner, 1987; Archer et al., 1988; Schauer et al., 1993; Jalava et al., 1998), and from stool and blood samples of children and adults (Tee et al., 1998; Sorlin et al., 1999). Strains described as 'Flexispira rappini' belong to the genus Helicobacter by phylogenetic analysis and share their unusual morphological features with several named Helicobacter species, including Helicobacter bilis (Fox et al., 1995) and Helicobacter trogontum (Mendes et al., 1996). Considerable diversity in the 16S rRNA gene of 35 strains that exhibit these distinctive morphological characteristics has been observed (Dewhirst et al., 2000). A polyphasic investigation of the relationships between all these strains is required to clarify the taxonomic position and status of this complex group within the genus Helicobacter. However, at present the name 'Flexispira rappini' refers to a characteristic morphotype shared by several distinct taxa, and not to a distinct well-defined species. We draw this fact to the attention of the scientific community that deals with these organisms.

\section{Matters regarding the etymology of specific or subspecific epithets of Campylobacter}

Members of the subcommitte had recently noted that several specific or subspecific epithets of Campylobacter taxa were erroneously formed. This required correction of the spelling of the epithet or, alternatively, correction of the etymology. The subcommittee members reached a consensus to correct the etymology of the specific epithets 'fetus' (of Campylobacter fetus), 'jejuni' (of Campylobacter jejuni), and 'mucosalis' (of Campylobacter mucosalis), and the subspecific epithet 'venerealis' (of C.fetus subsp. venerealis). The spelling of the biovar name 'fecalis' (of Campylobacter sputorum biovar fecalis) was corrected to 'faecalis'.

The correct etymologies for these five epithets are:

- fe'tus. L. masc. n. fetus fetus, fruit; L. gen. masc. n. fetus of a fetus;

- ve.ne.re.a'lis. M.L. (arbitrary) adj. venerealis pertaining to venereal disease;

- mu.co.sa'lis. M.L. adj. mucosalis pertaining to the (tunica) mucosa mucous membrane;

- je.ju'ni. M.L. gen. neut. n. jejuni of the jejunum;

- fae.cal'is. L. n. faex dregs; L. suffix -alis, adjectiveforming suffix: M.L. masc. adj. faecalis pertaining to faeces.

\section{References}

Alderton, M. R., Korolik, V., Coloe, P., Dewhirst, F. E. \& Paster, B. J. (1995). Campylobacter hyoilei sp. nov., associated with porcine proliferative enteritis. Int J Syst Bacteriol 45, 61-66.

Archer, J. R., Romero, S., Ritchie, A. E., Hamacher, M. E., Steiner, B. M., Bryner, J. H. \& Schell, R. F. (1988). Characterization of an unclassified microaerophilic bacterium associated with gastroenteritis. J Clin Microbiol 26, 101-105.

Bryner, J. H. (1987). Flexispira rappini gen. nov., sp. nov., a motile urease-producing rod similar to Campylobacter pyloridis. Proceedings of the Fourth International Workshop on Campylobacter Infections, Göteborg, Sweden. Abstract 256.

Dewhirst, F. E., Fox, J. G., Mendes, E. N., Paster, B. J., Gates, C. E., Kirkbride, C. A. \& Eaton, K. A. (2000). 'Flexispira rappini' strains represent at least ten Helicobacter taxa. Int J Syst Evol Microbiol 50, 1781-1787.

Fox, J. G., Yan, L. L., Dewhirst, F. E., Paster, B. J., Shames, B., Murphy, J. C., Hayward, A., Belcher, J. C. \& Mendes, E. N. (1995). 
Helicobacter bilis sp. nov., a novel Helicobacter species isolated from bile, livers and intestines of aged, inbred mice. $J$ Clin Microbiol 33, 445-454.

Jalava, K., On, S. L. W., Vandamme, P. A. R., Happonen, I., Sukura, A. \& Hänninen, M. L. (1998). Isolation and identification of Helicobacter spp. from canine and feline gastric mucosa. Appl Environ Microbiol 64, 3998-4006 (erratum 65, 877).

Mendes, E. N., Queiroz, D. M. M., Dewhirst, F. E., Paster, B. J., Moura, S. B. \& Fox, J. G. (1996). Helicobacter trogontum sp. nov. isolated from the rat intestine. Int J Syst Bacteriol 46, 916-921.

On, S. L. W., Costas, M. \& Holmes, B. (1994). Classification and identification of Campylobacter sputorum using numerical analyses of phenotypic tests and of one-dimensional electrophoretic protein profiles. Syst Appl Microbiol 17, 543-553.

On, S. L. W., Atabay, H. I., Corry, J. E. L., Harrington, C. S. \& Vandamme, P. (1998). Emended description of Campylobacter sputorum and revision of its infrasubspecific (biovar) divisions, including C. sputorum bv. paraureolyticus, a urease-producing variant from cattle and humans. Int $J$ Syst Bacteriol 48, 195-206.

Roop, R. M., Smibert, R. M., Johnson, J. L. \& Krieg, N. R. (1985). DNA homology studies of the catalase-negative campylo- bacters and 'Campylobacter fecalis', an emended description of Campylobacter sputorum, and proposal of the neotype strain of Campylobacter sputorum. Can J Microbiol 31, 823-831.

Schauer, D. B., Ghori, N. \& Falkow, S. (1993). Isolation and characterization of 'Flexispira rappini' from laboratory mice. $J$ Clin Microbiol 31, 2709-2714.

Sorlin, P., Vandamme, P., Nortier, J., Hoste, B., Rossi, C., Pavlof, S. \& Struelens, M. J. (1999). Recurrent 'Flexispira rappini' bacteremia in an adult patient undergoing hemodialysis: case report. J Clin Microbiol 37, 1319-1323.

Tee, W., Leder, K., Karroum, E. \& Dyall-Smith, M. (1998). 'Flexispira rappini' bacteremia in a child with pneumonia. $J$ Clin Microbiol 36, 1679-1682.

Vandamme, P., van Doorn, L.-J., Al Rashid, S. T., Quint, W. G. V., van der Plas, J., Chan, V. L. \& On, S. L. W. (1997). Campylobacter hyoilei Alderton et al. 1995 and Campylobacter coli Véron Chatelain 1973 are subjective synonyms. Int J Syst Bacteriol 47, 1055-1060.

Véron, M. \& Chatelain, R. (1973). Taxonomic study of the genus Campylobacter Sebald and Véron and designation of the neotype strain for the type species Campylobacter fetus (Smith and Taylor) Sebald and Véron. Int J Syst Bacteriol 23, 122-134. 